\title{
No right to liberty: the detention of asylum seekers for administrative convenience
}

\section{Helen O’Nions* \\ Introduction: the climate of non-entrée}

The recent decision of Grand Chamber of the ECtHR to endorse short periods of detention for asylum seekers on the grounds of practicality and administrative convenience appears to legitimise the indiscriminate and increasingly restrictive asylum policies of Western Europe ${ }^{1}$. The conclusion that necessity is not a requirement for detention in the asylum process may well lead to a dramatic increase in the number of people detained for comparatively short-periods. Such a practice is not accepted within the criminal justice sphere - thus a lesser standard applies when dealing with asylum detention, reflecting a view that asylum seekers are 'different' or 'others' whose human rights are limited by reason of their flight.

The reasons for the climate of restriction have been well-documented but should not be used to undermine the responsibility to provide sanctuary. Joseph Carens argues that there is a moral obligation which arises from the legitimacy of the nation-state system:

"the legitimacy of any particular state is thus initially derivative from the legitimacy of the system as a whole" ${ }^{2}$.

The nation-state system enables sovereign states to control their territory and exclude others; it is this process which generates refugees. As the nation seeks to firm up its identity those who do not fit neatly within that definition may find themselves excluded in a variety of ways. This obligation becomes greater as more refugees are created and does not diminish as the burden on the receiving state grows. Further, one can argue that once a state makes a decision to deny entry or expel a refugee they become implicitly linked to that person's destiny and become part of the

\footnotetext{
* Dr Helen O’Nions is a Senior Lecturer in Law at Nottingham Trent University, UK.

${ }^{1}$ Saadi v UK App 13229/03, judgement of $29^{\text {th }}$ January 2008

${ }^{2}$ Carens, Joseph “States and refugees: a normative analysis" in Adelman, Howard (ed) Refugee Policy. Canada and the US 1991 York Lanes Press, Toronto pp18-29 at 25.
} 
causative chain. Even if one doubts any pre-existing moral responsibility to those who flee persecution, it could be argued that such an obligation must arise when a decision is made to deny entry or to remove.

Mathew Gibney argues for a more pragmatic obligation on states which recognises the demands of impartialists such as Carens but also understands that states have a duty to their own citizens and the political community that they inhabit. He reasons that there is a humanitarian obligation to those who constitute refugees which is owed to those in most need ${ }^{3}$. This obligation is not absolute as it depends on the ability of the host-state to accommodate those seeking protection. Michael Waltzer argues that it may be necessary for states to restrict entry in order to maintain their own political community ${ }^{4}$.

In addition to any moral responsibility to admit refugees, which is certainly questioned by partialists, there is a legal right to seek and enjoy asylum enshrined in Article 14 of the Universal Declaration of Human Rights and a commensurate obligation to afford refugee status where a person complies with the Geneva Convention on the Status of Refugees ${ }^{5}$.

Nevertheless, non-entrée measures are increasingly used to prevent asylum seekers from accessing this legal right. The tough stance taken in Australia which has been well-documented appears to be finding favour in the US and Europe as an increasing number of people are detained in the absence of evidence that they pose a danger or that they may abscond. According to Frank

\section{Brennan:}

Detention of asylum seekers without visas has been used to transmit a double signal - warning other asylum seekers to take a detour to another country and luring voters who wish to take a tough stand against the 'other',

\footnotetext{
${ }^{3}$ Gibney, Mathew The Ethics and Politics of Asylum 2004 Cambridge Univ. Press.

${ }^{4}$ Waltzer, Michael Spheres of Justice 1983 Basic Books, New York p35-40.

${ }^{5}$ The wording of Article 14 is unfortunate in that it is not supported by a corresponding duty on states to provide asylum and it therefore offers the asylum seeker little assurance of sanctuary, Lauterpacht, $\mathrm{H}$ International law and Human rights 1950 Frederik Praeger at 422.

${ }^{6}$ Brennan, Frank Tampering with Asylum 2003 Univ. of Queensland Press, St Lucia pxiii.
} 
Whilst the European detention estate is growing $^{7}$ it is also diversifying. Hathaway, identifies several states which avoid the use of prisons and dedicated immigration detention centres preferring to use reception centres to accommodate asylum applicants ${ }^{8}$. This is often a matter of semantics, for example in Denmark and Germany the reception centre stay is often compulsory. In the Netherlands, asylum seekers are typically detained at these reception centres for the duration of their application. The government does not officially identify them as detention facilities as the occupants remain free to leave the country. Other states, such as Austria will deny support to asylum applicants who elect to reside outside the designated accommodation. In Croatia, Law 109/2003 provides that an asylum seeker will be detained in the Centre for Asylum Seekers during the duration of the application process unless they have sufficient resources to live independently in which case they will be detained for seven days ${ }^{9}$.

The Council of Europe's Committee on the Prevention of Torture suggest that conditions in these centres may be worse than those of prison establishments ${ }^{10}$. At the same time, several countries continue to use prisons to accommodate foreign nationals, including asylum applicants ${ }^{11}$. In the UK prisons may be used to detain immigration and asylum applicants despite UNHCR guidance that this should not occur. Officially the routine use of prisons ended following a government undertaking in October 2001 but it has been acknowledged that they will continue to be used in some cases where there may be a risk to security ${ }^{12}$. According to Home Office policy ${ }^{13}$, those

\footnotetext{
${ }^{7}$ Jesuit Refugee Service Detention in Europe October 2004 JRS listed 218 facilities for detaining migrants and asylum seekers in European 23 countries.

${ }^{8}$ Hathaway, James The Rights of Refugees in International Law 2005 Cambridge University Press at 378-9

${ }^{9}$ Gluščić, Stjepan Report to support to promotion of reciprocal understanding between the European union and the Western Balkans, National report, Justice and Home Affairs CEPOR (SME's policy think tank centre) 2005 http://www.cepor.hr/projekti/Justice.pdf

${ }^{10}$ CPT/Inf (2006) 11 Poland para 59; CPT/Inf (2006) 41 Greece; see also European Parliament Resolution on the situation with refugee camps in Malta

${ }^{11}$ European Committee for the Prevention of Torture, inhuman or Degrading Treatment or Punishment. Visit report: Ireland (2006) CPT/Inf (2007) 40; CPT/Inf (2007) 18 Visit report: Germany, para 49 Hamburg remand prison is used to detain male and female foreign nationals with a view to expulsion alongside remand prisoners.

${ }^{12}$ David Blunkett HC deb. 25 ${ }^{\text {th }}$ Feb 2002 col. 442.

${ }^{13}$ Home Office Operational Enforcement Manual as of 2007, Chapter 38.10.1.
} 
who engage in disruptive activities whilst in detention may be transferred to prisons ${ }^{14}$. In Poland, asylum seekers can be detained in a specific detention facility or a deportation prison for up to a year if they have made an application whilst illegally in Poland or awaiting deportation ${ }^{15}$.In addition, private prison service operators now run many of the immigration detention centres in the UK . According to research by Christine Bacon, these companies see immigration detention as a logical extension of their role and clearly perceive their involvement as "firmly within the penal sphere” ${ }^{16}$.

The detention of asylum-seekers is normally justified in order to facilitate impending expulsion or where there is a concern that the individual may abscond. As such it is compatible with Article 5(1)f ECHR. However, recent times have seen a gradual departure from this justification to embrace detention for purely administrative purposes. As such the legal requirements to avoid arbitrariness and to act proportionately are threatened. The stage is being set for a move towards the Australian model of mandatory detention. In the UK, these moves began in the early 1990's with the Conservative government's perception that the country had become a 'soft-touch' for asylum seekers ${ }^{17}$. Similarly, the 1996 immigration reforms in the United States changed the direction of immigration policy in favour of increased restrictions and hostility by redefining persons who are not lawfully present as not yet admitted so as to deprive them of extended appeal rights $^{18}$. Routine detention has recently been introduced against asylum-seekers arriving from a list of countries on the basis of generalised national security concerns ${ }^{19}$.

\footnotetext{
${ }^{14}$ This was the case following the Yarlswood riots in 2004.

${ }^{15}$ Visit: Poland (2004) CPT/Inf (2006) 11

${ }^{16}$ Bacon, Christine "The evolution of immigration detention in the UK” RSC Working Paper no 272005 Refugee Studies Centre, Univ. of Oxford at2

${ }^{17}$ Young, Craig "Political representations of geography and place in the introduction of the U.K. Asylum and Immigration Act (1996)” in Nicholson and Twomey (eds) Current issues of UK Asylum Law and Policy 1998 Ashgate (1998) p34-51 at 43.

18 “The US perspective” Paolo Morante 85-112 in Hughes, Jane and Liebaut, Fabrice (eds) Detention of asylum seekers in Europe: analysis and perspectives Kluwer 1998, The Hague at 92; see also Dow, Mark American Gulag. Inside US immigration Prisons 2004 Univ. of California Press, Berkeley and Welch, Michael Detained. Immigration Law and the expanding INS jail complex 2002 Temple Univ. Press, Philadelphia.

${ }^{19}$ Human Rights Watch “US ‘Operation Liberty Shield’ Undermines Asylum seekers rights” March $27^{\text {th }} 2003$
} 
Restrictive measures may be explained by the notion that asylum seekers 'choose' particular states, which they see as a 'soft touch' offering generous welfare packages. This is related to the inaccurate perception in the West that the majority of asylum seekers target European states to seek protection ${ }^{20}$. Gibney observes that 'from the early 1990's Western countries seemed to fall like dominoes to the problem of asylum, ${ }^{21}$. Des Places attributes this response to the perceived problem of asylum shopping whereby asylum seekers select countries of destination based partly on a perception that they are more generous with their reception of asylum seekers. Applying regulatory competition theory, she argues that this fear led to a competitive restrictionism amongst states ${ }^{22}$. Whilst this may account for state responses, the restrictionist argument fails to take account of a diverse range of 'pull factors' which direct an asylum seeker to a particular country. Such factors include a common language, past colonial ties and geographical proximity ${ }^{23}$. In other cases, the choice of destination falls to smugglers and traffickers rather than the individual applicant. Castles and Loughna point to a "multi-faceted "migration industry" which operates to influence the 'decision' ${ }^{24}$.

Whilst the numbers seeking asylum in the UK have decreased in recent years, it is doubtful whether this can be simply attributed to the increasing climate of restriction ${ }^{25}$. Research suggests that restrictionism has limited success in reducing the number of applicants. In 1992 Australia introduced mandatory detention for asylum seekers and yet the numbers continued to rise steadily until Australia closed its borders and rejected boat arrivals in Sept $2001^{26}$. In the UK, the Home

\footnotetext{
${ }^{20}$ Castles, S and Loughna, S note that Tanzania accommodated around 500,000 refugees in 2000 in "Trends in asylum migration to industrialized countries 1990-2001” in Borjas, G and Crisp, J Poverty, International Migration and Asylum 2005 Palgrave pp39-69 at 53. There is no doubt that those countries immediately surrounding areas of conflict, such as Pakistan, Iran and Turkey have accommodated a far greater number of refugees.

${ }^{21}$ Gibney, Matthew Beyond the bounds of responsibility: western states and measures to prevent the arrival of refugees Global Migration Perspectives No 22 Jan 2005, Global Commission on International Migration, Geneva at 6.

${ }^{22}$ Des Places, Ségolène Barbou Evolution of asylum legislation in the EU: insights from regulatory competition theory EUI Working Papers 2003/16 European University Institute, Italy.

${ }^{23}$ supra n20 at 61 .

${ }^{24}$ supra n20 at 63.

${ }^{25}$ Zetter, Griffiths, Feretti and Pearl An assessment of the impact of asylum policies in Europe 1990-2000 July 2003

Home Office Research Study.

${ }^{26}$ Field and Edwards Alternatives to detention of asylum seekers and refugees UNHCR Legal and Protection Policy Research Series POLAS/2006/03 April 2006 Appendix 1, Australia.
} 
Office undertook its own study which suggested that there is no correlation between more restrictive policies and a decline in the number of asylum applicants ${ }^{27}$. Yet this remains a perception amongst many politicians. At the same time, there can be no doubt that increasing restrictionism prevents people from accessing the asylum process and may force many people to remain in danger. The measures aimed at targeting asylum abuse are indiscriminate in their application.

In addition to well-publicised measures such as carriers liability, visa requirements and the stationing of immigration officers at overseas ports; we have begun to see a process of territorial contraction with the use of international zones which are considered to be outside the full jurisdiction of potential host states. Gibney notes:

With only mild exaggeration one might say that a thousand little Guantanamos have been created in the last two decades: centres of power where states (and their formal and informal agents) act free from the constraints imposed on their activities by the courts, international and domestic law, human rights groups and the public at large ${ }^{28}$.

Similarly the policy of interdiction is used to redirect asylum seekers to separate regions in order to process their claims. This received international attention in the Tampa incident of 2001 where the asylum claimants were eventually directed by the Australian government to the pacific island of Naru to have their claims assessed ${ }^{29}$. Such developments threaten the legitimacy of international refugee law and have attracted criticism from the UNHCR:

Many industrialized countries have increasingly 'externalized' their border controls, including through interception in the territorial waters or territory of third states with the latters' permission and/or involvement. In some regions, asylum policies became increasingly control-oriented and seen as a sub-set of migration policies ${ }^{30}$.

\footnotetext{
${ }^{27}$ Zetter et al supra $n 25$.

${ }^{28}$ Gibney supra $n 21$ at 9 notes that the original use of Guantanamo was to house Cuban and Haitain asylum seekers in the early 1990's.

${ }^{29}$ Gibney supra n21 at 9.

${ }^{30}$ General Assembly EX Com of the High Commissioners programme 58th session "Note on international protection" A/AC.96/1038 $29^{\text {th }}$ June 2007 para 30.
} 
Refugee advocates understand that there are few if any legal means of flight open to asylum

seekers who are in need of protection ${ }^{31}$.

James Hathaway argues:

Instead of embracing the Refugee Convention's solution of temporary protection, the response of developed states to the end of the interest-convergence between refugees and receiving States has been to avoid receiving claims to refugee status. Most Northern states have implemented non-entrée mechanisms, inc visa requirements on the nationals of refugee-producing states, carrier sanctions, burden shifting arrangements, and even the forcible interdiction of refugees at frontiers and in international waters. The simple purpose of non-entrée strategies is to keep refugees away from $\mathrm{us}^{32}$.

In her critique of international refugee law, Patricia Tuitt has argued that the definition of refugees and asylum-seekers in Western Europe has been both racialised and criminalised through the use of detention and entry controls ${ }^{33}$. The focus on the racial or ethnic origins of the refugee can then be used to argue that mass migration is economic at its source ${ }^{34}$. Furthermore she contends:

Being thus pragmatically focused, international refugee law constantly turns away from the needs of the refugee and towards the sovereign interests of Western states...this has resulted in an irreparable conflict between international refugee law and the refugee ${ }^{35}$.

Tuitt believes that the domination of the Geneva Convention conception of refugee has allowed us to marginalise and exclude those who do not fit neatly within this definition, labelling them as undeserving, bogus claimants ${ }^{36}$. This exclusion is justified by reference to the increasing resort to forged documents and traffickers without cognisance of the causative factors ${ }^{37}$.

Whilst governments may see some success in tightening entry procedures, Michael Samers adopts a virtualist perspective to argue that illegal immigration may in fact be created and

\footnotetext{
31 This was expressly acknowledged by the Home Office Minister, Lord Rooker, in January 2002 HL debates Hansard $23^{\text {rd }}$ January 2002 Col 1462.

${ }^{32}$ Hathaway, James Reconceiving International Refugee Law 1997 M Nijhoff , The Hague pxx.

${ }^{33}$ Tuitt, Patricia The Law's Construction of the Refugee 1996 Pluto London at 19-20.

${ }^{34}$ ibid. at 19.

${ }^{35}$ ibid. at 23.

${ }^{36}$ ibid. at 146.

${ }^{37}$ ibid. at 148 .
} 
encouraged by these stricter regulations and the notion of immigration as 'potentially dangerous' which has helped to close off legal routes ${ }^{38}$.

The extended use of detention, whilst not strictly a non-entrée measure itself may appear to be part of a package of measures aimed at deterring asylum seekers from seeking refuge ${ }^{39}$. The typical rationale for detention in Europe has been to effect deportation or removal when the individual is not compliant ${ }^{40}$. This would appear to satisfy any concerns regarding necessity and proportionality. However, the recent move towards more routine use of detention may be viewed in part as deterrence-based. Such a rationale for detention is expressly prohibited by international law and one should expect to find that when detention is employed its use is restricted to situations where it is deemed to be 'necessary' and proportionate to the legitimate objectives (as prescribed by domestic and international law).

\section{International law on the detention of asylum seekers}

Although Article 14 of the Universal Declaration of Human Rights provides a right to seek asylum, it is clear from international human rights law that there is no right to enter a state or a right to be granted asylum. There are some limitations provided in terms of removals and the principle of non-refoulment but these provisions fall well short of any state obligation to recognise an individual as a refugee ${ }^{41}$.

In order to understand the nature of international obligations in this area it is necessary to consider both international refugee law and human rights law. Article 31(1) of the Geneva Convention prohibits penalties applied to refugees on account of their illegal entry or presence where they present themselves to the authorities without delay and show good cause for their illegal entry or presence. Indeed, Hathaway notes that Article 31 “denies governments the right to

\footnotetext{
${ }^{38}$ Samers, M “An emerging geopolitics of 'illegal’ immigration” EJML 2004 Vol 6 27-45 at 29.

${ }^{39}$ Goodwin-Gill "Article 31 of the 1951 Convention relating to the status of refugees: non-penalization, detention and protection” pp185-258 in Feller, Türk and Nicholson Refugee protection in international law 2003 UNHCR at 225.

${ }^{40}$ Hughes and Liebaut supra $n 18$ at 21.
} 
subject refugees to any detriment for reason of their unauthorized entry or presence in the asylum country ${ }^{42}$. As the object of the provision is to prevent punishment for illegal entry, GoodwinGill adopts a broad interpretation of 'penalty' to encompass detention ${ }^{43}$. However, it also seems clear that a brief period of detention pending an investigation is not defined as a penalty within Art 31 but is merely an administrative measure ${ }^{44}$. Hathaway notes that detention prior to regularization does not constitute a penalty within Article $31(2)^{45}$. Regularization occurs when the asylum applicant has satisfied the formal requirements for verification of refugee status. This suggests that once an applicant has complied with the procedural requirements of the refugee determination procedure any further detention would constitute a penalty unless defined as 'necessary ${ }^{46}$. Grahl-Madsen argues that detention can be employed in order to ascertain identity and to assist the investigation but it is limited by the requirement of necessity ${ }^{47}$. He specifically rules out the legitimacy of detention for administrative convenience ${ }^{48}$. The requirement for an individual assessment is of paramount importance. The UNHCR's commentary suggests that restrictions on movement should only occur when necessary and then should be afforded a narrow interpretation ${ }^{49}$. Article 31(2) requires that restrictions should be:

Be prescribed by law

Be necessary

Not be discriminatory

Be applied only until status is regularised or until the person obtains admission elsewhere $^{50}$.

\footnotetext{
${ }^{41}$ Goodwin-Gill and McAdam The Refugee in International Law 2007 OUP at 366.

42 Hathaway supra 8 at 410

${ }^{43}$ Goodwin-Gill supra n39 at 195.

${ }^{44}$ Giakoumopoulos, Christos “Detention of asylum seekers in the light of Art 5 of the ECHR' in Hughes and Liebaut supra $n 18$ pp161-182 at 165.

${ }^{45}$ Hathaway supra $\mathrm{n}$ at 418

${ }^{46}$ Gill and McAdam supra n41 at 462.

${ }^{47}$ Grahl-Madsen, Atle The Status of Refugees in International Law Sijthoff, Leiden 1972 at 148.

48 ibid. at 150.

${ }^{49}$ Landgren, Karin "Comments on the UNHCR position on detention of refugees and asylum seekers” in Hughes and Liebaut supra $n 18$ pp141-160 at 146.

${ }^{50}$ Field supra n26 para 74.
} 
On first glance, the international refugee law obligations may appear more demanding than those of international human rights $\operatorname{law}^{51}$ as they specifically require necessity rather than simply a lack of arbitrariness ${ }^{52}$. Ultimately, such an assessment will depend on the interpretative reach of arbitrariness.

\section{The concept of arbitrariness}

The notion that detention should not be arbitrary is well rehearsed in international human rights and refugee law. The UNHCR's guidelines on detention of asylum seekers state that freedom from arbitrary detention is a 'fundamental human right' ${ }^{53}$. Article 9 of the International Covenant on Civil and Political Rights provides, inter alia, that no-one shall be subject to arbitrary arrest or detention and the Human Rights Committee’s General Comment no 8 on the Right to Liberty and Security of Persons, specifically includes immigration control $^{54}$.This does not make all immigration detention per se unlawful but, as Edwards argues, it requires the decision-maker to consider alternatives such as sureties and reporting mechanisms prior to detention ${ }^{55}$. In $\mathrm{A} \mathrm{v}$ Australia, the Human rights committee specifically linked necessity to the assessemnt or arbitrariness:

“...remand in custody could be considered arbitrary if it is not necessary in all circumstances of the case, for example to prevent flight or interference with evidence: the elemnt of proprotionality becomes relevant in this context”,56

This is particularly the case when the applicant has a specific vulnerability, such as a psychiatric illness, as confirmed by the Human Rights Committee in $C v$ Australia ${ }^{57}$.

\footnotetext{
${ }^{51}$ Article 9 ICCPR and Article 5(1) ECHR.

${ }^{52} \mathrm{Cf}$ Goodwin-Gill and McAdam supra n41 at 463

${ }^{53}$ UNHCR Revised guidelines on applicable criteria and standards relating to the detention of asylum seekers Feb 1999 UNHCR para 1.

${ }^{54}$ HRC General Comment No 8 Right to Liberty and Security of Persons (Art 9) 30 ${ }^{\text {th }}$ June 1982 para 1.

${ }^{55}$ Edwards, Alice "Human rights, refugees and the right 'to enjoy' asylum” 17 IJRL (2005) 293-330 at 319

${ }^{56}$ A v Australia Communication No 560/1993 CCPR/C/59/D/560/1993

${ }^{57}$ Communication No 900/1999 CCPR/C/76/D/900/1999
} 
It is contended that this is not simply an assessment of legality but is broader and should be defined as 'substantive arbitrariness' to include decisions which are unreasonable, unjust, delayed and unpredictable ${ }^{58}$. Detention may thus be lawful but nevertheless arbitrary and could then constitute a breach of Article $9^{59}$. Art 12 ICCPR protects the freedom of movement of those 'lawfully’ within the state’s territory. Asylum applicants are regarded as being 'lawfully resident' by the Human Rights Committee for the purpose of this provision ${ }^{60}$. Art 12 (3) stablishes that restrictions on freedom of movement must be provided by law and be necessary to protect national security, public order, health or morals or rights and freedoms of others.A restriction is therefore necessary when its severity and intensity are proportional to one of the purposes listed in this article and when it is related to one of these purposes ${ }^{61}$.

The definition of arbitrary detention is informed by the UN Working Group on Arbitrary Detention which was established in 1991 by the UN Human Rights Commission to investigate situations of arbitrary detention. In December 1998 the Working Group set out criteria for determining whether custody is arbitrary ${ }^{62}$. Their 1998 report on the UK expressed concern over the lack of judicial oversight and emphasised that detention should only be used when legitimate according to international standards and where other measures will not suffice ${ }^{63}$. The report lists 14 criteria which could be used to determine whether custody is arbitrary - these criteria only apply once a decision to detain has been made in accordance with the law, thus the issue of necessity is not explored in this context. However, the report recommends that alternative and non-custodial measures, such as reporting requirements, should always be considered before

\footnotetext{
${ }^{58}$ Commission on Human Rights On right to be free from arbitrary arrest, detention and exile UN Doc.E/CN.4/826/Rev.1 paras23-30.

${ }^{59}$ Van Alphen v Netherlands No 305/1988 UN Doc CCPR/C/39/D/305/1988 (1990).

${ }^{60}$ Celepi v Sweden Communictaion No 456/1991 CCPR/C/51/D/456/1991

${ }^{61}$ Nowak, M UN Covenant on Civil and Political Rights- CCPR Commentary 1993 Engel Verlag, Kehl am Rhein, Strasbourg p211; Goodwin-Gill supra n39 at 223.

${ }^{62}$ Report of the Working Group UN Doc E/CN.4/1999/63 $18^{\text {th }}$ Dec 1999.

${ }^{63}$ Commission on Human rights $55^{\text {th }}$ Session Civil and Political rights, including torture and detention "Report of the Working Group on arbitrary detention” E/CN.4/1999/63 18 ${ }^{\text {th }}$ Dec 1998.
} 
resorting to detention ${ }^{64}$ and that: "the detaining authorities must assess a compelling need to detain that is based on the personal history if each asylum seeker”65.

One UK non-governmental refugee organisation, Bail for Immigration Detainees (BID), provided a submission to the UN Working group on arbitrary detention in Sept 2002:

From our experience of detention and bail procedures BID is forced to conclude that detention is employed in the UK as a deterrent to those seeking asylum. Furthermore, the lack of procedural safeguards leads to widespread arbitrary detention. This submission offers recommendations to end this unlawful practice ${ }^{66}$.

The Executive Committee's Conclusion on detention of refugees and asylum seekers in $1986^{67}$ emphasised the need for necessity to be related to one of the legitimate aims stated; these aims have now been updated by the 1999 Guidelines which describe detention as inherently undesirable ${ }^{68}$. The introduction to the guidelines emphasises the need for necessity in all cases. Guideline 2 cites Article 14 UDHR and states the general principle that 'asylum seekers should not be detained, ${ }^{69}$. The exceptions to this principle must be prescribed by law and should only be applied following consideration of all the alternatives ${ }^{70}$. They are contained in guideline 3 :

- To ascertain identity

- To determine the elements on which the claim is based, but not for the duration of the decision-making process or indefinitely

- In cases of bad faith where the asylum seeker has destroyed travel documents or has used fraudulent documents intentionally to mislead the state authorities

- To protect national security or public safety

\footnotetext{
${ }^{64}$ ibid. recommendation 8, para 33.

65 ibid. 9, para 34.

${ }^{66}$ Bail for Immigration detainees Submission to the UN Working group on arbitrary detention Sept 2002 Executive summary.

${ }^{67}$ Ex Com Conclusion 44 (XXXVII) 1986 A/AC.96/688.

${ }^{68}$ UNHCR Revised Guidelines on applicable criteria and standards for the detention of asylum seekers UNHCR 1999 para 1.

69 ibid.

${ }^{70}$ The possible alternatives include regularly reporting and monitoring mechanisms, provision of a surety or guarantor, release on bail and open accommodation centres: Guideline 4.
} 
The $2^{\text {nd }}$ exception might be interpreted to provide justification for short-term, administrative detention but it is clear from the accompanying paragraph that it is only envisaged for a temporary period for the purpose of a preliminary interview. Furthermore:

...it would not extend to a determination of the merits or otherwise of the claim. This exception to the general principle cannot be used to justify detention for the entire status determination procedure, or for an unlimited period of time.

According to the UNHCR's interpretation of the international legal position, detention outside these exceptions is contrary to accepted legal norms. The scope of arbitrary detention was discussed by the Executive Committee in a Standing Committee ${ }^{71}$. Their definition suggests a broad, purposive approach:

...detention of asylum seekers may be considered arbitrary if: it is not in accordance with the law; if the law itself allows for arbitrary practices, or is enforced in an arbitrary way; when it is random or capricious or not accompanied by fair and efficient procedures for its review. It may also be arbitrary if it is disproportionate, or indefinite...For detention not to be arbitrary it should be prescribed by law that is sufficiently accessible and precise, and it should not include elements or inappropriateness or injustice ${ }^{72}$.

Furthermore, the Committee concluded, inter alia:

"Arbitrary detention of asylum-seekers and refugees occurs when they are detained for insufficient reason, without adequate analysis of their individual circumstances...”73.

In relation to Art 31(2), the expert roundtable organised by the UNHCR in Geneva $8-9^{\text {th }}$ Nov 2001confirmed the exceptional nature of detention and required individualised assessments:

the detention of refugees and asylum-seekers is an exceptional measures and should only be applied in the individual case, where it has been determined by the appropriate authority to be necessary in the light o the circumstances of the case and on the basis of criteria established by law in line with international refugee and human rights law. As such, it should not be applied unlawfully and arbitrarily and only where it is necessary for the reasons outlined in Ex Comm 44 in particular for the protection of national security and public order... ${ }^{74}$.

More recently, the UNHCR has avoided being prescriptive on the subject. EX Com No 93 (LIII) 2002 on reception of asylum-seekers in the context of individual asylum systems requires merely

\footnotetext{
${ }^{71}$ Executive Committee of the High Commissioner's programme Standing Committee Detention of asylum-seekers and refugees: the framework, the problem and recommended practice EC/49/SC/CRP.13 $4^{\text {th }}$ June 1999.

72 ibid. para 10.

${ }^{73}$ ibid. para 25.
} 
that states respect human dignity and applicable human rights law when choosing a suitable reception arrangement. The Conclusion does not address the specific issues arising in the context of detention in reception centres and appears to allow states a degree of latitude when making such assessments ${ }^{75}$.

It is commonly understood that approach of the Human Rights Committee under the ICCPR should inform the Council of Europe institutions when interpreting the ECHR. Indeed Article 53 of the ECHR expressly recognises the importance of international human rights obligations. Furthermore, Articles 31-33 of the Vienna Convention on the Law of Treaties requires an interpretation which is consistent with other international law obligations, thus necessity, proportionality and lack of arbitrariness must be key aspects in the interpretation of Article 5(1)f of the Convention.

The Council of Europe has also engaged with the issue of detaining asylum seekers and has offered recent clarification on the subject of arbitrary detention. Recommendation Rec. (2003) 5 On measures of detention of asylum seekers establishes the circumstances in which detention can be justified. The list is exhaustive:

- When their identity, including nationality, has in case of doubt to be verified, in particular where travel or identity documents have been destroyed

- When elements on which the asylum claim is based have to be determined which, in the absence of detention, could not be obtained

- When a decision needs to be taken on their right to enter the territory of the state concerned, or

- When protection of national security and public order so require ${ }^{76}$.

\footnotetext{
${ }^{74}$ para $11 \mathrm{~b}$ in Feller et al supra n39 at256.

${ }^{75}$ EX Com No 93 (LIII) 2002 on reception of asylum-seekers in the context of individual asylum systems para b, i and vi; Landgren supra n49 at 150.

${ }^{76}$ para 3.
} 
In $A v$ Australia, the Human Rights Committee specifically required that the detention be justified on an individual basis:

the fact of illegal entry may indicate a need for investigation and there may be other factors particular to the individual, such as likelihood of absconding and lack of cooperation, which may justify detention for a period. Without such factors detention may be considered arbitrary, even if entry was illegal ${ }^{77}$ (my emphasis)

The UNHCR have also emphasised the need for the 'detaining authorities must assess a compelling need to detain that is based on the personal history of each asylum-seeker, ${ }^{78}$. This approach is also found in the $\mathrm{C} / \mathrm{E}$ recommendation which requires that these cases are dealt with on their individual merits and that detention should be necessary in each case:

Measures of detention of asylum seekers should be applied only after a careful examination of the necessity in each individual case. Those measures should be specific, temporary and non-arbitrary and should be applied for the shortest possible time

and furthermore:

Alternative and non-custodial measures, feasible in the individual case, should be considered before resorting to measures of detention ${ }^{79}$.

The consideration of alternatives to detention is a recurrent theme in the international soft law ${ }^{80}$. The UNHCR's Executive Committee has provided that the power to detain must be defined clearly and narrowly and that there should be an individual assessment of the suitability of detention with a consideration of the alternatives ${ }^{81}$. According to Ophelia Field, the consideration of non-custodial alternatives is a 'pre-requisite for satisfying the principle of necessity in relation to lawful detention, ${ }^{82}$. Arbitrariness may also occur where an applicant is denied adequate

\footnotetext{
771997 Comm 560/1993 3 $3^{\text {rd }}$ Apr 1997 para 9.4, also discussed by Tootell, Hughes and Petrasek “The relevance of key UN instruments for detained asylum seekers” in Hughes and Liebaut supra n18 at189.

${ }^{78}$ supra $\mathrm{n} 81$ at para $26(\mathrm{~b})$.

${ }^{79}$ C/E Recommendation Rec. (2003) 5 On measures of detention of asylum seekers para 6.

${ }^{80}$ Although there is little hard law providing state obligations in this field.

${ }^{81}$ Executive Committee of the High Commissioner's programme "Detention of asylum-seekers and refugees: the framework, the problem and recommended practice” Standing Committee $15^{\text {th }}$ Meeting $4^{\text {th }}$ June 1999 EC/49/SC/CRP.13 para 14.

${ }^{82}$ Field supra n26 para 70.
} 
reasons for the detention, this obligation is continuous in that the detention may become unlawful if the reason given initially ceases to apply ${ }^{83}$.

Thus, according to international soft law, for a decision to satisfy the absence of arbitrariness test, it should be based on the individual circumstances of the applicant and should proceed from a consideration of alternatives which are found to be inappropriate in the applicant's case.

Article 5 ECHR contains the presumption of liberty and any interference must be for one of the specific purposes only. The detention must be lawful in that it is prescribed by law, complies with the rule of law and it should avoid arbitrariness ${ }^{84}$. In the cases of Amuur v France and Shamsa v Poland a lack of clarity regarding the process of detention violated the requirements that the procedure was prescribed by law ${ }^{85}$.

Generally, the exceptions to Article 5 are narrowly construed by the Strasbourg authorities. The ECtHR has insisted that effective and regular judicial supervision is a key element of detention in the criminal justice process. In Brogan $v U K^{86}$, the detention of terrorism suspects for periods of four and seven days was held to breach the requirement for suspects to be bought promptly before a judicial authority ${ }^{87}$. It is also clear that there must be reasonable grounds for suspicion before a person can be detained. Similarly if a person of 'unsound mind' is to be detained there must be a medical assessment of necessity to ascertain that the person is suffering from a mental illness ${ }^{88}$.

The need to consider all the alternatives to detention has been emphasised by the ECtHR in Litwa $v$ Poland ${ }^{89}$ concerning the detention of alcoholics under Article 5(1)e. The court made it clear that the purpose of Article 5 was the prevention of arbitrariness ${ }^{90}$. They also held that:

The detention of an individual is such a serious measure that it is only justified where other, less severe measures have been considered and found to be insufficient to safeguard the individual or public interest which might require that the person concerned be detained. That means that it does not suffice that the

\footnotetext{
${ }^{83}$ Chahal v UK (1996) 23 EHRR 413.

${ }^{84}$ Clayton, Gina Textbook on Immigration and Asylum Law OUP 2004 at 433.

${ }^{85}$ App No 19776/92 of $25^{\text {th }}$ June 1996 and App Nos 45355/99 and 45357/99 of Nov $27^{\text {th }} 2003$ respectively.

${ }^{86}$ Brogan v UK (1989) 11 EHRR 117

${ }^{87}$ Article 5(1)3 ECHR.

${ }^{88}$ Cornelisse supra n165 at105.

${ }^{89}$ App No 26629/95 4.4.2000.

${ }^{90}$ para 73.
} 
deprivation of liberty is executed in conformity with national law but must also be necessary in the circumstances $^{91}$ (my emphasis).

The right to liberty is limited by Article 5(1)f which allows detention in two situations i) to prevent the person from unauthorised entry into the UK ii) where an action of removal is to be affected. In the latter scenario, it has been clear since the decision of the ECtHR in Chahal $v$ UK that detention does not need to be 'necessary' although it is also clear that detention can only be justified if the removal proceedings are in progress and are being processed with due diligence ${ }^{92}$.

\section{Recent developments in the EU}

Following the Treaty of Amsterdam in 1997, the European Union has become increasingly active in the asylum field. An explicit right to asylum is contained in Article 18 of the non-binding Charter on Fundamental Rights but, when implemented, this will not add to existing human rights standards $^{93}$.

Since January 2005, the Directive on the Reception of Asylum Seekers should have been transposed into the domestic law of all member states ${ }^{94}$. The directive addresses the issue of detention but stops short of imposing detailed obligations on states. Most significantly, Article 7(2) allows member states to decide on the asylum seeker's residence for reasons of public order, public interest or 'where necessary for the swift processing and effective monitoring of applications'. The original proposal explained that this provision should rule out the detention of applicants simply because they are applicants, which would suggest that administrative simplicity should not be the determinative factor in detention ${ }^{95}$. When the directive was considered by the House of Lords Select Committee in 2001 the issue of necessity was raised: "At the very least,

\footnotetext{
${ }^{91}$ para 78.

${ }^{92}$ Chahal $v$ UK (1996) 23 EHRR 413 at 464-466.

${ }_{93}$ Art 51(2) which states that the charter does not establish any new power or task for the community or union.

94 2003/9/EC of $27^{\text {th }}$ January 2003. For analysis see ECRI The EC Directive on the Reception of Asylum Seekers: Are asylum seekers in Europe receiving material support and access to employment in accordance with European legislation? AD3/11/2005/EXT/SH.
} 
restriction should only be implemented when strictly necessary” ${ }^{96}$. Yet the issue of necessity is not tied to the individual applicant's case and the UNHCR have expressed criticism of this provision and its potential for broad interpretation ${ }^{97}$.

Alternatively, lesser restrictions on movement, such as a designated region of residence, are foreseen by Article 7(3) and in these cases administrative convenience may be a factor ${ }^{98}$. The final text watered down the initial proposal which advocated the consideration of alternatives before any restriction on movement. In terms of the conditions of detention, the directive is notably silent apart from para 10 which requires that the reception of applicants in detention should be designed to meet their needs in that situation

In addition to the reception directive, a directive on Minimum procedures for the Granting and withdrawing of Refugee status ${ }^{99}$ was established which says little on the subject of detention. Article 18 merely requires that member states should not detain a person for the sole reason that they are an asylum applicant and requires access to a speedy judicial review ${ }^{100}$. The directive generated a great deal of criticism by refugee groups ${ }^{101}$ and the UNHCR has been critical of efforts to harmonize asylum procedures, especially the increasingly restrictive aspects which may breach international standards ${ }^{102}$. More specifically, the UNHCR has cautioned strongly against the use of a list of 'safe countries' without an assessment of individual risk ${ }^{103}$.

\footnotetext{
${ }^{95}$ Brussels, 3.4.2001 COM(2001) 181 final 2001/0091 (CNS) Proposal for a Council Directive laying down minimum standards on the reception of applicants for asylum in Member States (presented by the Commission) Article 7(2).

${ }^{96}$ HL European Union select Committee $8^{\text {th }}$ session "Minimum standards for reception conditions of asylum seekers with evidence” Nov 2001.

${ }^{97}$ UNHCR Annotated Comments on Council Directive 2003/9/EC of 27 $7^{\text {th }}$ January 2003 laying down minimum standards for the reception of asylum seekers May, 2007 UNHCR.

${ }^{98}$ Mitsilegas, Valsamis "The directive on the reception of asylum seekers and its implementation in the UK” IANL 2996 Vol. 20(1) p42-45 at 44.

${ }^{99}$ 2005/85/EC $1^{\text {st }}$ Dec 2005.

100 2005/85/EC $1^{\text {st }}$ December 05 Article 18.

${ }^{101}$ ECRE Press releases $30^{\text {th }}$ Sept 03, 29 $9^{\text {th }}$ March 04

102 UN GA Ex Comm of High Commissioners 55th session “Note on International Protection” A/AC.96/989 July 7th 2004 para 15.

${ }^{103}$ UNHCR ‘Note on International protection’ UN Doc A/AC.96/975 2 ${ }^{\text {nd }}$ Jul 2003 para 12.
} 
The use of generalised assessments of safety is relevant to the debate on detention, as it may be a chief factor in the decision to detain following the designation of the case as clearly unfounded ${ }^{104}$.

Art 27 requires states to ensure an individual case by case assessment of safety of particular states but in fact member states are able to develop their own approaches on this question and it specifically permits national designation ${ }^{105}$. In addition, Article 29 empowers the European Council to draw up a list of safe countries of origin; member states are expected to deem those countries as safe and may add to but not subtract from this list. Annex II provides the criteria '...it can be shown that there is generally and consistently no persecution as defined in Art 9'. The generalised approach of the directive is certainly problematic in the light of the prohibition on non-refoulement. In particular there is concern that it may result in refugees in orbit or 'chain refoulement' ${ }^{106}$.

In 1995, the Commission issued a proposal for a new directive on common standards and procedures for returning illegally staying third-country nationals ${ }^{107}$. The proposal is directed at ensuring speedy removal from the European area and includes provision for a European re-entry ban. Article 14 endorses temporary custody but only where there are serious grounds for believing that there is a risk of absconding' and where less coercive measures can not be applied. Temporary custody is subject to judicial supervision but may be extended to a max of 6 months ${ }^{108}$. Whilst it is envisaged that such custody will be in specialised detention facilities, there

\footnotetext{
${ }^{104}$ Young supra n17 at45 criticises the UK's designation of Nigeria as 'safe' after the murder of the Ogoni activist Ken Saro-Wiwa.

${ }^{105}$ Art 27(2)b. Art 30.

${ }^{106}$ Goodwin-Gill and McAdam supra $n 41$ at 397 and p400; ECRE 'Broken promises' June 2004; Tuitt supra n33 at 111; Trost, Rachel and Billings, Peter “The designation of 'safe' countries and individual assessment of asylum claims” pp73-99 in Nicholson and Twomey supra n17.

${ }^{107}$ Proposals for a Directive of the European Parliament and of the Council on common standards and procedures in member states for returning illegally staying third-country nationals COM(2005) 391 Final $1^{\text {st }}$ Sept 2005

${ }^{108}$ Article 14
} 
is nevertheless recognition, despite extensive international criticism, that as a last resort, it may also be provided in the prison system ${ }^{109}$.

The European Union has become very active in maintaining its external frontiers by funding initiatives on the periphery of Europe to detain and remove asylum applicants. One such location is Ukraine where an estimated 40,000 people per annum travel illegally to the EU. The conditions in these centres are miserable and do not attract the same degree of scrutiny as those in EU states $^{110}$.

There are mixed messages coming from the various European political institutions. The European Parliament has recently labelled European immigration policy as a failure, highlighting the number of migrants that have died in the Mediterranean trying to enter the EU ${ }^{111}$. The Resolution on the common immigration policy ${ }^{112}$, states that, inter alia, detention is contrary to the Geneva Convention and that administrative detention is leading to serious breaches of human rights $^{113}$.

Some commentators have called for an enlightened approach to immigration and asylum using Article 12 of the Treaty establishing the European Community which prohibits any discrimination on the grounds of nationality. This would only allow distinctions in treatment to be permitted in the interests of immigration control if they are proportionate and justified. In cases where fundamental rights are at stake then distinctions should be prohibited without the option of justification ${ }^{114}$. A draft directive On minimum guarantees for individual freedom, security and justice in relation to decisions regarding movement of persons was proposed by the Standing Committee of Experts in International Immigration, Refugee and Criminal Law in 2004. The draft directive suggested prohibiting discrimination in the use of detention as well as entry control

\footnotetext{
109 Article 15

${ }^{110}$ BBC news “Ukrainian detention centre” Friday $13^{\text {th }}$ Dec 2002; see also Make Borders History Campaign “No Border camp. Ukraine” August 2007

111 para L

112 European Parliament Resolution on the common immigration policy B6-0508/2006 $26^{\text {th }}$ Sept 2006

113 paras 11,12
} 
and removal ${ }^{115}$. It also provides for basic protections such as legal representation including free legal aid where needed and far greater judicial control of administrative immigration decisions ${ }^{116}$. The premise of the directive is the need to protect liberty, security and free movement in contrast to the minimum standards directive. It is based on the codification of existing standards in community law, notably the Charter on Fundamental rights and European Convention case law.

\section{Playing the definitions game}

Some states have re-defined the detention of asylum seekers in an attempt to avoid international obligations and criticism. Instead detention may be chracterised as a restriction on movement which may engage Protocol 4, Article 2 ECHR $^{117}$. In Germany, asylum seekers may be held at international airports until a decision is reached ${ }^{118}$. The authorities argue that this is not detention as the individuals are free to return to their country of origin or a transit country. Nevertheless, the same practice was held to constitute a deprivation of liberty within Article 5 ECHR in Amuur $v$ France concerning four Somali nationals who had been held at Paris-Orly airport ${ }^{119}$. The French government had argued they were not detained on French territory but were in an 'international zone' and therefore the Article 5 obligations did not apply. It was also suggested that there was no deprivation of liberty as the men were free to return to a safe country. A distinction may be drawn between a deprivation of liberty which engages Article 5 and a restriction on movement which falls within Article 2 of Protocol 4. In Raimondo $v$ Italy $^{120}$ the applicant was suspected of involvement with the Mafia. He had been confined to his home in the evenings and had to inform the police when he planned to leave. However, he did not require

\footnotetext{
${ }^{114}$ Boeles, Pieter “Editorial: fair and effective immigration procedures in Europe?” 2005 EJML Vol. 7 pp213-218 at 218.

115 Articles 1, 2.

${ }^{116}$ Boeles, Brouwer, Woltjer and Alfenaar "Draft directive on minimum guarantees for individual freedom, security and justice in relation to decisions regarding movement of persons” 2005 EJML Vol. 7 pp301-319.

${ }^{117}$ Mole, Nuala and Harby, Catharina Immigration, Asylum and detention ECRE, AIRE Centre June 2004

${ }^{118}$ Wilkinson, Ray “Europe: the debate over detention” Refugees Magazine, UNHCR Issue 113.

119 (1996) 22 EHRR 533

${ }^{120}$ [1994] 18 EHRR 237
} 
permission to leave his home and therefore this engaged the 4th protocol rather than Article 5. The protection offered by Article 5 is far greater than that of the $4^{\text {th }}$ protocol which only applies to persons lawfully within the territory of the state. Thus, if short-term detention is defined as merely a restriction on movement it would legitimise its routine use against asylum-seekers. The Amuur decision and the legal rationale for the decision in Raimondo suggest that this is not the case. Asylum applicants are typically detained in an environment which they are not free to leave by simply giving notice.

The UNHCR's Executive Committee has noted that the use of such temporary accommodation without adequate facilities constitutes de facto detention and in many cases there is evidence that may suggest inhuman and degrading treatment ${ }^{121}$.

In the UK, detention centres were renamed reception and removal centres in the Nationality, Immigration and Asylum Act 2002, although the function of the centres remains the same. It seems clear that whether the centre is described as an accommodation or removal centre the obligations to avoid arbitrariness remain. According to Lord Bassam:

It does not signal a change of function for such centres. They will remain designated places of detention for the purposes of the Immigration Act. Similarly, it does not signal a change to the powers to detain ${ }^{122}$.

The power to detain asylum seekers in the UK

The power to detain was originally confined to cases of impending removal by Schedule 2 of the Immigration Act 1971 as amended by s140(1) Immigration and Asylum Act (IAA 1999) and s73(5) Nationality, Immigration and Asylum Act 2002 (NIAA 2002). This power was extended by s62 of NIAA 2002 to provide a free-standing power for the Secretary of State to authorise detention in cases where there is a power to issue removal directions.

\footnotetext{
${ }^{121}$ Executive Committee of the High Commissioner's programme "Detention of asylum-seekers and refugees: the framework, the problem and recommended practice” Standing Committee $15^{\text {th }}$ Meeting $4^{\text {th }}$ June 1999 EC/49/SC/CRP.13 para 20. There now appears to be international consensus that such transit zones are places of detention - Giakoumopoulos, Christos “Detention of asylum seekers in the light of Art 5 of the ECHR' pp161-182 in Hughes and Liebaut supra $n 18$ at 172

${ }^{122}$ Lord Bassam HL debates Col $108122^{\text {nd }}$ July 2002.
} 
Immigration Officers are constrained by the Home Office's Operation Enforcement Manual (OEM). The OEM makes express reference to Article 5 ECHR and specifies that, in order to be lawful, detention must be for a specific purpose under Article 5; for a reasonable period for as long as the purpose of detention remains valid; and, that the detaining authority should act with due diligence and expedition in effecting removal (or for whatever the purpose of the power is) ${ }^{123}$. The OEM also refers to Article 8 ECHR and the obligation to ensure that such decisions are proportionate to the legitimate aim of ensuring an effective immigration policy. In $R$ (on the application of I) $v$ of SSHD [2002] Lord Dyson reasoned that detention must clearly be justified in all the circumstances of the individual case ${ }^{124}$.

Whilst the objectives of the law governing immigration detention may be clear, such as the need to prevent absconding and thereby effect removal, the decision-making process itself is insufficiently prescriptive and there is a lack of statutory regulation. The organisation Bail for Immigration Detainees (BID) claim to have been aware of cases where procedures in the manual are not followed, including where an applicant had been discourteous to an immigration officer and where they had failed to complete particular forms and travel documents ${ }^{125}$. Research by Gelsthorpe corroborates this assertion; one immigration officer stated:

..I decide myself. Yes there are criteria, but I don't think they're particularly clear or particularly helpful. I think they're all very vague and it's really the CIO at the end of the day who makes the decision ${ }^{126}$.

This discretion and absence of statutory guidance, makes it difficult for such decisions to be challenged.

There is no maximum period of detention in the UK. The most recent Home Office statistics state that 1435 asylum seekers were detained on $31^{\text {st }}$ March 2007 with Oakington accounting for the

\footnotetext{
${ }^{123}$ OEM Chapter 38.1.1

${ }^{124}$ EWCA Civ 888.

${ }^{125}$ BID Submission to the UN Working Group on Arbitrary Detention 2002 BID Part 4.2.

${ }^{126}$ Weber and Gelsthorpe Deciding to Detain: how decisions to detain asylum-seekers are made at points of entry Cambridge Institute of Criminology 2002 at 73.
} 
largest proportion. However, the specific length of detention for adults is not recorded ${ }^{127}$. In June 2006, 80 asylum seekers had been detained for between 6 months and 1 year and 45 had been detained for more than a year ${ }^{128}$. In some cases extended detention is blamed on the delay in receiving travel documents from the country or origin and in others, it is alleged that administrative convenience plays a large part ${ }^{129}$. This was recognised by the Human Rights Committee in $2001^{130}$.

There is clearly a lack of transparency evidenced by an absence of specific data. It is not known how many immigration detainees are still accommodated in prisons and data on the number of child detainees is difficult to obtain ${ }^{131}$. Whilst the Home Office's website provides some of the data it only provides a snapshot on a particular day and avoids much of the uncomfortable detail. Given the absence of specific data on the number of people detained and the length and grounds for the detention, the UN Working Group recommended:

“national authorities should provide detailed information on relevant policy, practice and statistics in order to ensure transparency" ${ }^{132}$.

The reasons for the decision to detain should be given in writing at the time of detention and thereafter at monthly intervals. According to rule 9 of the Detention Centre Rules of April 2001,more detailed written reasons are to be given to detainees at monthly intervals. However, it would appear that this decision is often presented as a list of ticked boxes on a checklist ${ }^{133}$. Research by BID suggests that the vast majority of detainees had not been given information consistent with the criteria in the $\mathrm{OEM}^{134}$.

\footnotetext{
${ }^{127}$ Home Office Asylum statistics $1^{\text {st }}$ quarter 2007 Table 13.

$1282^{\text {nd }}$ quarter 2006 Table 13.

${ }^{129}$ BID supra 125 at para 4.9.

${ }^{130}$ Concluding observations of the Human Rights Committee: UK and N Ireland UN Doc CCPR/CO/73/UK and CCPR/CO/73/UKOT 6 ${ }^{\text {th }}$ Dec 2001.

${ }^{131}$ According to the SSHD there were 67 minors detained with their families on March $22^{\text {nd }} 2007$ - Hansard $16^{\text {th }}$ April 2007 Col 461W.

${ }^{132}$ UN Working Group Recommendation 13, para 40.

${ }^{133}$ Home Office Operational Enforcement Manual July 2001 Chapter 38.6.

${ }^{134}$ BID supra n125 para 4.6.
} 
The OEM contains separate rules for fast-track cases which were updated in February 2006. This procedure is designed specifically for cases that can be determined quickly - the detained fast track suitability list consists of countries which are considered to be generally free from persecution which can thus generate quick decisions ${ }^{135}$. Certain categories are excluded from the fast track mechanisms including those with age disputes, disabled applicants, pregnant women (over 24 weeks) and people with certain illnesses that require hospitalisation or 24 hour nursing care, those with criminal convictions (except where authorised), violent or uncooperative cases and those where detention would be contrary to published criteria ${ }^{136}$.In such cases the authority to detain must be given by the Chief Immigration Officer or a senior caseworker ${ }^{137}$ and a formal and documented review should be made after 24 hours by an Inspector and thereafter at weekly intervals ${ }^{138}$.

The consideration of alternatives to detention, although advocated in international law, is not apparent in UK immigration policy. The Council of Europe’s Commissioner for Human Rights recently expressed concern that detention for administrative reasons in the UK may become the norm. He advocated more use of open processing centres with on-site accommodation for the efficient resolution of claims ${ }^{139}$. BID contend that despite the government's intention to use alternatives to detention 'wherever possible ${ }^{140}$, there has been little research into possible alternatives and in some cases, decisions to detain are made when the person already had temporary admission and has outstanding appeal rights exercisable from the UK. This is also

\footnotetext{
${ }^{135}$ Chapter 38.3.1 OEM On $27^{\text {th }}$ Feb 2001 the Home Secretary listed the following nationalities as suitable for Oakington detention: Albania, Bangladesh, China, Czech Republic, Estonia, China, Iraq, India, Kosova, Latvia, Lithuania, Nigeria, Pakistan, Poland, Romania, Slovakia, Tanzania, Uganda, Zimbabwe.

${ }^{136}$ OEM Chapter 38.3.

${ }^{137}$ OEM Chp 38.5.

138 OEM Chp 38.8.

${ }^{139}$ Council of Europe Commissioner for Human Rights, Mr Gil Alvaro-Robles Report on visit to the UK $4^{\text {th }}-12^{\text {th }}$ Nov 2004 CommDH(2005)6 para.66

${ }^{140}$ OEM Chp 38. 1.
} 
emphasised in research by Weber and Gelsthorpe which suggests that there had been a goal-shift from the published reasons justifying detention to that of deterrence ${ }^{141}$.

\section{The Oakington regime}

The Home Office policy published in 1998 provided that persons liable to be detained under schedule 2, para 16 (1) and 2(1) Immigration Act 1971 were initially to be detained only to clarify the nature of their claim and ascertain their identity. Thereafter they were temporarily admitted unless there was a reason to assume that they may not comply with the conditions of their temporary admission. From March 2000, the policy was changed in relation to detention at Oakington reception centre which had been established in order to process certain applications speedily.

It was envisaged that most people detained at Oakington reception centre would be detained for around 7 days. Indeed, the Minister responsible assured the House of Commons that applicants whose cases were not determined within a period of 'around 7 days' should be granted temporary admission or moved to another place of detention ${ }^{142}$. According to Ian Martin, Oakington Project Manager, the rationale of Oakington was not centred on the prevention of absconding but rather on the need to process claims quickly and efficiently ${ }^{143}$. Detainees have access to onsite legal advice and services unlike many other detention facilities where access to legal advice is often a major difficulty ${ }^{144}$. The weekly cost of detention at Oakington in 2002 was calculated to be $£ 1620$ per person ${ }^{145}$.

In 2005 the regime at Oakington was subject to a BBC undercover documentary which identified many incidents of racism, physical abuse and incompetence amongst the employees of Global

\footnotetext{
${ }^{141}$ Weber and Gelsthorpe, supra n 126.

${ }^{142}$ Barbara Roche HC Col 263W $16^{\text {th }}$ March 2000.

${ }^{143}$ Quoted in Saadi v SSHD [2002] UKHL 41 at 3137.

${ }^{144}$ HC Select Committee on European Union, Minutes of Evidence Memorandum by HM Inspectorate of prisons $1^{\text {st }}$ Feb 2006.

${ }^{145}$ HC Deb. 25 Oct 2001 Col 333W.
} 
Solutions Ltd who run the centre ${ }^{146}$. An inquiry by the Prisons and Probation Ombudsman followed. The ombudsman accepted the findings of the BBC investigation and produced a critical report with many key recommendations for staff to follow ${ }^{147}$. Between April 2006 and March 2007 there were 12 reported incidents of self harm at Oakington and the HMI report for 2006 raised concern about the risk of suicide and self-harm as well as the lack of enforced procedures on anti-bullying and anti-racism ${ }^{148}$. The future at Oakington is uncertain; it was widely speculated that the centre would close by the end of 2006 yet it now seems that it has another three years to run. Following criticism from monitoring groups and the international community, women and families are no longer detained. In the $4^{\text {th }}$ quarter of 2006 it housed 155 male applicants ${ }^{149}$.

The limited period of detention at Oakington may be followed by temporary admission. However, it may also result in detention at an alternative institution and thus it is important to regard Oakington as one element in the system of immigration detention rather than a separate, specific institution dealing only with fast-track applications. In theory, detainees have been sifted before arrival, yet it is alleged that this is not happening and people who are victims of torture, rape and trauma who require detailed psychological evaluation are not receiving $\mathrm{it}^{150}$.

The presumption underlying detention at Oakington is that applicants can be fast tracked with a view to speedy removal ${ }^{151}$. Indeed the most recent sets of statistics indicate that $100 \%$ of applicants had their initial application refused and of these one-third then appealed against refusal $^{152}$. This absolute rate of initial refusal may be used to validate initial decisions to

\footnotetext{
${ }^{146}$ BBC Detention Undercover: The real story 2005.

${ }^{147}$ Inquiry into allegations of racism and mistreatment of detainees at Oakington immigration reception centre and while under escort July 2005.

${ }^{148}$ HM Chief Inspector of Prisons Report on a short follow-up inspection of Oakington Reception Centre $5-7^{\text {th }}$ June 2006.

${ }^{149}$ IND Asylum Statistics $4^{\text {th }}$ quarter 2006.

${ }^{150}$ Burnham, Emily Challenging Immigration Detention. A best practice guide Oct 2003 ILPA, BID at 18; Amnesty International Seeking asylum is not a crime: detention of people who have sought asylum 2005 Amnesty international UK 2005.

${ }^{151}$ Select Committee on Home Affairs $2^{\text {nd }}$ report, part 6 Detention and Removal 2004.

${ }^{152}$ Home Office asylum statistics $1^{\text {st }}$ quarter 2007 March 31st 07Table 17,18 . This figure is the same for the $4^{\text {th }}$ quarter of 2006.
} 
detain ${ }^{153}$, yet caution must be exercised in assuming this conclusion, as it could equally be indicative of poor quality, hurried decision-making. In the Saadi case all applicants were rejected at first instance and subsequently found to have credible cases.

\section{The Saadi challenge}

The decision of the HL in the case of Saadi and Others ${ }^{154}$ established that a short period of detention at Oakington on the basis of administrative convenience, does not violate Article 5 ECHR. The decision was upheld by a narrow majority in the ECtHR and has recently been upheld by the Grand Chamber ${ }^{155}$.

The reasoning employed in Saadi demands great scrutiny as it confirms a distinction suggested in Chahal $v$ UK, namely that asylum seekers have less of a right to liberty than those suspected of criminal offences and persons of unsound mind ${ }^{156}$.

Saadi and others were Kurds living in the Autonomous region in Northern Iraq who fled Iraq and claimed asylum immediately on arrival in the $\mathrm{UK}^{157}$. The substance of their asylum claims need not concern us as all were eventually recognised as having a genuine need for protection by the Home Office (despite having their initial applications rejected). Dr Saadi had initially been granted temporary admission and asked to return to the airport on two occasions. He complied with these instructions but on the second occasion he was detained at Oakington reception centre for seven days. The view of the HL was that the detention did not have to be necessary to prevent absconding or actions against the public good and further, that all entry was unauthorised until it was expressly authorised by the Home Office and therefore, providing the action of detention was

\footnotetext{
153 This has been argued by the Home Office as justification for detention, Amnesty International Seeking asylum is not a crime: detention of people who have sought asylum 2005 Amnesty international UK 2005 at 62.

${ }^{154} R$ (on application of Saadi) $v$ SSHD [2002] UKHL 41, [2002] 1 WLR 3131.

155 Saadi v UK [2007] 44 EHRR 50; Grand chamber judgement of $29^{\text {th }}$ January 2008

${ }^{156}$ For more on the differential treatment in the UK see Bacon supra n16 at 3

${ }^{157}$ The policy of return to the Kurdish autonomous area of Northern Iraq is discussed in the seminar by ILPA and Redress Non-refoulement under threat Redress, London Nov 2006 at 29.
} 
proportionate, the detention fell within the exceptions listed in Art 5(1)f ECHR ${ }^{158}$. The HL placed great emphasis on the ability of a state to control its own borders within the limits conferred by statute and international obligations. Lord Slynn emphasised that the Article 5(1)f power is to 'prevent' unauthorised entry and that until the state specifically authorised entry, the entry must be seen as unauthorised. The state thus has power to detain until the entry is formally authorised $^{159}$. There is therefore no need to show that the individual was seeking to evade immigration control. Lord Slynn's approach can be contrasted with that of Justice Collins in the High Court who reasoned that if the applicant had done all that he reasonably could to report to the authorities and did not present a risk of misbehaviour, he could in no way be regarded as effecting unauthorised entry ${ }^{160}$.

Lord Slynn rejected the implication of necessity in the second limb of Article 5(1) and reasoned that both limbs required the same approach:

If necessity for detention is to be shown, it is more appropriate to require it for someone who has been lawfully here and who is then arrested and detained with a view to deportation because of his conduct here than for someone who has recently landed and who has never been lawfully here under authorised entry ${ }^{161}$

The HL declined to consider the application of the non-discrimination provision in Article 14. However, they did find a breach of Article 5(2) as Dr Saadi was not informed of the reason for his detention for a period of 76 hours.

\section{The decision of the ECtHR}

Saadi is the first case where the meaning of 'unauthorised entry' is debated at length by the ECtHR. It is clear from the facts that none of the four applicants were attempting to effect an unlawful entry as they had applied for asylum as soon as the opportunity availed itself. In

\footnotetext{
${ }^{158} R$ (on application of Saadi) $v$ SSHD [2002] UKHL 41, [2002] 1 WLR 3131.

${ }^{159}$ p3142. For commentary on Saadi see Berkowitz, Nathalia “Article 5, detention of asylum seekers” IANL 2006 p20

(3) 223-225; "Immigration and asylum: detention of asylum seeker for speedy processing of application” EHRLR 2006, $6742-745$.

160 [2001] 4 All ER 961 para 29.

161 supra $\mathrm{n} 158$ at 3143.
} 
referring to the 'states' 'undeniable right to control aliens' entry into and residence in their country” ${ }^{\prime 62}$, the Grand Chamber upheld the approach of the HL by concluding that until a potential immigrant has been officially granted leave to remain, he has not effected a lawful entry ${ }^{163}$. He could thus be detained under Art 5(1) f as detention would be aimed at preventing unlawful entry.

On the issue of necessity, the decision of the Court emphasised the need to subject detention decisions to close scrutiny. However, they felt that decisions to detain people who had uncertain immigration status should confer a broader discretion on states than detention under other paragraphs of Article $5^{164}$. The reasons for this margin of appreciation have not been specifically elucidated, but Cornelisse suggests that it may be a reflection of the Court's assumptions about the relative importance of certain rights and interests in particular the emphasis on national sovereignty and territoriality ${ }^{165}$.

Whilst the Grand Chamber recognised that detention must not be arbitrary, this could be separated from a requirement of necessity;

To avoid being branded as arbitrary..such detention must be carried out in good faith; it must be closely connected to the prupose of preventing unquthorised entry of the person to the country; the place and conditions of detention should be appropriate... and the length of the detetion should not exceed that reasonably required for the purpose pursued ${ }^{166}$

it did not, contrary to the other exceptions in Article 5, have to be necessary.

162 [2007] 44 EHRR 50 para 40 citing Amuur v France App No 19776/92 of 25 $5^{\text {th }}$ June 1996 para 41.

163 Grand Chamber [2008] para.65

164 [2007] 44 EHRR para 44

${ }^{165}$ Cornelisse, Galina "Human rights for immigration detainees in Strasbourg: limited sovereignty or a limited discourse?” 2004 EJML Vol. 6 93-110 at 105.

${ }^{166}$ Grand Chamber [2008] para 74 
In applying these factors to Dr Saadi's detention, it was found that the authorities had acted with good faith in order to speedily process the aplication and that this purpose of detentionwas closely connected to the purpose of preventing unauthorised detention. Under the third criteria, the conditions at Oakington were considered to give no particular cause for concern ${ }^{167}$.

This separation of arbitrariness from necessity leads to a false dichotomy; as Liberty have recognised:

The arbitrary nature of such detention will be exacerbated if the Grand Chamber upholds the Chamber's view and gives states complete freedom to deprive all asylum seekers of their liberty whilst their claims are processed $^{168}$.

In addition, the presumption that all entry is unauthorised until expressly authorised undermines the status of people fleeing persecution. The international right to seek asylum is surely deprived of much of its meaning if its exercise results in a deprivation of liberty. Of particular concern is the fact that the reasoning of the Grand Chamber blurs the distinction between immigrants and asylum seekers. Indeed, The UNHCR submitted observations following the initial ECHR decision in which they asserted the need to maintain a clear distinction between those seeking asylum and ordinary immigrants ${ }^{169}$. Asylum seekers are entering in order to exercise a lawful right to seek and enjoy asylum and therefore should not properly be regarded as trying to enter illegitimately:

Properly construed. Article 5(1)f should confer robust protection against detention for ayslum seekers. The sub-paragraph stipulated a purpose, the effecting of an unauthorised entry, which detention must prevent. Asylum seekers had to be distinguished from general classes of illegal entrant or those facing deportation, and in order to detain asylum seekers...there had to be something more that the mere absence of a decision on the claim; the detention had to be necssary, in the sense that less instrusive measures would not suffice, and proportionate to the aim pursued ${ }^{170}$

The Grand Chamber's interpretation also seems at odds with the approach taken by the HRC on the right to freedom of movement provided by Article 12 ICCPR. The HRC has held that an illegal entrant whose status has been regularised is lawfully within the state for the purpose of

\footnotetext{
${ }^{167}$ Ibid paras 77-78

${ }^{168}$ Intervention of AIRA Centre, ECRE and Liberty and submission to the Grand Chamber of the ECHR Para 5.

${ }^{169}$ Grand Chamber [2008] para 54
} 
Article $12^{171}$. Ophelia Field contends that this must apply equally to an asylum seeker who has been admitted to the asylum process ${ }^{172}$. Thus she observes a paradox whereby a person's presence may be simultaneously lawful and yet, according to the ECtHR in Saadi, unauthorised. In this respect international human rights law, particularly Articles 9 and 12 ICCPR, appear to offer greater protection to that of regional protection. Unfortunately, neither provision was given significant attention in the reasoning of the Grand Chamber.

The Dissenting opinions of Judges Rozakis, Tulkes, Kovler, Hajiyev, Spielmann and Hirvelä

Six judges presented a joint dicision which dissents from the judgement on Article 5(1)f. Their opinions refdlect the concerns expressed by the Aire Centre, Liberty and the UNHCR. In particular they note the danger of assimilating asylum seekers to ordinary immigrants which sits at odds with the interpretation that asylum seekers are lawfully within the state's territory under Article 12 ICCPR.

They also doubt whether the fast-track detention process complies with the requirement of 'good faith'. In particular they criticise the line of reasoning which suggests that the fast-track system is in the best interest of the asylum applicants:

...to maintain that detention is in the interests of the person concerned appears to us an exceedingly dangerous stance to adopt. Furthermore, to contend in the present case that the detention is in the interests not remely of the asylum seekers themselves "but of those increasingly in the queue" is equally unacceptable. In no circumstances can the end justify the means: no person, no human being may be used as a means towards an end

They echo the opinions of the earlier dissenting Judges Casadevall, Traja and Šikuta in that the majority interpretation of unauthorised entry creates great uncertainty for all asylum applicants that have not received specific authorisation on entry; they may be liable to detention at any time. Criticism is also directed at the lack of weight afforded to a consideration of alternatives which has been regarded as an essential part of the assessment process in international soft law.In

170 ibid 
reality, the interpretation of the majority in both Chambers of the ECHR appears to be at odds with the international legal provisions and also with regional statements from the Council of Europe and the European Union.

Further challenges under Article 5(2) and 14

The Grand chamber upheld the decision of the HL and the CA by ruling, unanimously, that Article 5(2) was violated as Saadi had not been made sufficiently aware of the reasons for his detention.

However, lamentably they declined to consider the argument concerning an alleged breach of the non-discrimination provision in Article 14. This argument is crucial to understanding the detention process at Oakington which categorises people on the basis of their nationality for fast-track removal.Detention is typically justified by refence to a general assessment of assessment of the credibility of applicants from a particular region - without adequate consideration of the particular claimant's case. Indeed this is a key element of the 'clearly unfounded' category of applicants who find themselves fast-tracked for removal. It has also become a key element of EU policy under the new Procedures Directive.

Under s19D Race Relations Act 1976, as inserted by the Asylum and Immigration (Treatment of Claimants) Act 2004, it is possible for an immigration officer to use nationality criteria in order to subject persons to more rigorous examination; to impose conditions on entry and to detain ${ }^{173}$. These nationalities must have been specifically approved by the Secretary of State on the basis that the particular nationality has generated a significant number of breaches of immigration law or adverse decisions; or on the basis of intelligence information regarding the propensity of

\footnotetext{
${ }^{171}$ Celepli v Sweden HRC Case 456/1991.

${ }^{172}$ Field supra n26 para 34.

173 para 3(2).
} 
persons of that nationality attempting to breach or breaching immigration control; or there is statistical evidence to show an emerging trend in breaches or adverse decisions by person of that nationality ${ }^{174}$. Thus the domestic law allows for differential treatment on the basis of authorisation by the Secretary of State. However, the domestic law must also correspond to international human rights law - in particular Article 14 ECHR which would require the exercise of such powers to be based on legitimate interests and proportionality.

\section{$\underline{\text { Beyond Saadi }}$}

The ruling in Saadi can be limited to the specific process of detention at Oakington and other fasttrack processing centres. The confinement was considered neither arbitrary nor disproportionate given its limited duration and the conditions of the detention. Lord Slynn reasoned:

if conditions in the centre were less acceptable than they are taken to be there might be more room for doubt but it seems to me that the need for speed justified detention for a short period in acceptable physical conditions as being reasonably necessary ${ }^{175}$.

However, it is contended that if requirements of necessity and proportionality are not strictly applied to immigration detention, as they are with other restrictions on movement, states might be encouraged to extend the use of detention which would not need to be justified ${ }^{176}$. It seems a big leap to say that because detention under Article 5(1)f does not need to be strictly 'necessary', it can be undertaken for administrative convenience. Such an argument could lead to an exponential increase in short-term detention across Europe.

Allowing administrative convenience to justify any deprivation of liberty, albeit defined as 'shortterm', seems to be a very dangerous precedent. Liberty has argued that neither administrative convenience nor a short duration of detention can be used to satisfy the requirement that detention is not arbitrary ${ }^{177}$. Cornelisse contends that any assessment of arbitrariness must include

\footnotetext{
${ }^{174}$ Race Relations (Immigration and Asylum) Authorisation 2004

175 supra $\mathrm{n} 158$ at 3139.

${ }^{176}$ para 50.

${ }^{177}$ Aire Intervention supra n168 para 6.
} 
inappropriateness, injustice, lack of predictability and due process of the law. Proportionality will be intrinsic to the assessment or arbitrariness ${ }^{178}$. In Daly ${ }^{179}$, the House of Lords adopted a threestage test in order to establish whether a decision was proportionate: i) the legitimate objective should be sufficiently important to justify limiting a fundamental human right; ii) the measures designed to meet the objective should be rationally connected to it; and iii) the means used to impair the right or freedom should be no more than necessary to accomplish this objective. The legitimate objective is the provision of immigration control and the use of detention is connected to this objective so it becomes particularly important to focus on the third element which must involve a consideration of the length and conditions of detention.

\section{Detention conditions}

It is important that the length of detention and the conditions of detention should be separated in any consideration of arbitrariness. Detention conditions have been criticised at a number of institutions in the UK and Europe. Thus it is unfortunate that the House of Lords, limited by their supervisory role in judicial review, were unable to scrutinise the regime at Oakington when making their assessment of proportionality. It is evident that even short-term detention can have detrimental effects on detainees. Such issues have been raised by the Chief Inspector of Prisons, Ms Anne Owers, whose report on five Heathrow holding centres found children and single men held together. It was observed that conditions were 'dehumanising' and that detainees were treated as 'parcels rather than people; and parcels whose contents and destination were sometimes incorrect ${ }^{180}$. There are many more acute concerns raised about the conditions of detainees at other removal and detention centres which are beyond the scope of this paper ${ }^{181}$. Yet, it is clear

\footnotetext{
${ }^{178}$ Cornelisse supra $\mathrm{n} 165$ at 96.

${ }^{179} R$ (on the application of Daly) $v$ SSHD 2001 UKHL 26.

${ }^{180} \mathrm{HM}$ Inspector of Prisons Report on the unannounced inspections of five non-residential short-term holding facilities: Queen's Building and Terminals 1-4 Heathrow Airport 10-13 ${ }^{\text {th }}$ Oct 2005 at 5.

${ }^{181}$ HM Chief inspector of Prisons Report on unannounced inspection of Harmondsworth Immigration Removal Centre $17-21^{\text {st }}$ July 2006. The report revealed that over $60 \%$ of detainees felt unsafe and $44 \%$ said they had been victimised by staff. The regime at Lindholme has also been criticised by Anne Owers for its 'prison culture' and lack of respect for
} 
from the BBC investigation, discussed above, that abuse and dehumanisation can occur in the comparatively brief period of detention at Oakington ${ }^{182}$.

The parliamentary Joint Committee on Human Rights have been scathing of the process of detention for administrative convenience. They were particularly concerned over the possibility of detaining torture victims who may feel unable to communicate the full extent of their experiences to the authorities. This concern may be more acute with the accelerated, fast-track procedure which may deny applicants sufficient opportunity to reveal ill-treatment prior to detention ${ }^{183}$. The committee also criticised of the lack of judicial control in administrative detention and the absence of a maximum time limit; recommending that if detention is unavoidable the maximum period should be 28 days ${ }^{184}$. Concern was expressed about lack of appropriate medical provision in detention and the lack of information, including reasons for detention, given to asylum detainees ${ }^{185}$. Furthermore, the Committee noted the failure of the Home Office to develop alternatives to detention ${ }^{186}$. In response to this criticism, the government emphasised the use of reporting procedures and the option of electronic tagging under s36 Immigration and Asylum (treatment of claimants) Act 2004. It is submitted that electronic tagging may further criminalise asylum seekers and this is borne out by the fact that if the individual refuses to have a tag fitted they can be liable to detention and prosecution ${ }^{187}$.

As well as constituting a potential breach of Article 5, poor detention conditions have engaged Articles 3 and 8 of the ECHR. In Mayeka $v$ Belgium $^{188}$ a 5 year old girl whose mother had been

the detainees BBC News "Prison culture at asylum centre" $16^{\text {th }}$ June 2004. June 2007, up to 100 detainees at Dungavel removal centre in Scotland were refusing food following the suicide of Kurdish asylum seeker. Specific issues included lack of legal representation and the indefinite time limit of the detention with a view to deportation (in some cases more than 18 months) BBC News “Food protest by asylum detainees" $11^{\text {th }}$ June 2007

182 See page 22 .

183 Joint Committee on Human Rights $10^{\text {th }}$ report: the treatment of asylum seekers 2007 para 226.

${ }^{184}$ HL and HC Joint Committee on Human Rights “Government response to the Committee's tenth report of this session: the treatment of asylum seekers” $17^{\text {th }}$ report of session 2006-7 HL Paper 134, HC $7905^{\text {th }}$ July 2007 paras 274 and 275, 276 respectively.

${ }_{186}^{185}$ para 305 and 310 respectively.

${ }_{186}$ para 329.

187 "Government response to the Committee's tenth report of this session: the treatment of asylum seekers" $17^{\text {th }}$ report of session 2006-7 HL Paper 134, HC $7905^{\text {th }}$ July 2007 para 55.

$18813178 / 03$ Oct $12^{\text {th }} 2006$ unreported. 
recognised as a refugee in Canada arrived in Belgium to meet her uncle who was resident there. She was held in a detention centre largely occupied by adults with no support. She was refused permission to reside with her Uncle whilst her status was considered and was then removed to the DR Congo with no family to meet her. This was held to constitute a violation of Articles 3, 8 and Article 5 (unanimously).

In the Greek Case the European Commission found that political detainees had experienced overcrowding, inadequate sleeping and toilet facilities, insufficient food, recreation and contacts with outside world which could constitute a violation of Art $3^{189}$. The denial of adequate medical treatment may also lead to a violation ${ }^{190}$. Violations of Article 3 were also found in Peers $v$ Greece and Dougoz v Greece ${ }^{191}$.

The CPT regularly reviews detention practices across Europe and has expressed criticism of the standards in several European countries ${ }^{192}$. The UK report focused particularly on those detained indefinitely under s23 ATCSA 2001 - a practice which has now ended following the HL decision A v Home Office [2004] ${ }^{193}$. The Committee noted that these individuals could not be removed as they would face ill-treatment or torture on their return thus they were in a legal limbo and their mental health had suffered dramatically as a result ${ }^{194}$.

Amnesty International's 2005 report 'Seeking Asylum is not a crime' contains interviews with several detainees, including families detained in the UK despite having complied with all Home Office instructions ${ }^{195}$. Many expressed concern over the lack of information regarding the reasons and length of detention. Such complaints are equally applicable to short periods of detention; in

\footnotetext{
${ }^{189}$ YB 121969.

${ }^{190}$ Hurtado $v$ Switzerland Series A No 280-A.

191 App No 28524/95 April $19^{\text {th }} 2001$ and App 40907/98 March $6^{\text {th }} 2001$ respectively.

192 CPT/Inf (2007) 18 of $18^{\text {th }}$ April 2007 reports on detention conditions in Germany; CPT/Inf (2006) 1 of $20^{\text {th }}$ December 2006 criticises two centres in Greece; CPT/Inf (2005) $1321^{\text {st }}$ July 2005 criticises detention prior to deportation in Austria; CPT/Inf (2006) $923^{\text {rd }}$ February 2006 describes conditions in Lithuania as 'unacceptable'.

${ }^{193}$ UKHL 56.

${ }^{194}$ CPT/Inf (2006) 28 of $10^{\text {th }}$ August 2006.

195 Amnesty International supra n150.
} 
one case a torture-survivor and her daughter had been detained at Oakington for ten days ${ }^{196}$. This is clearly in contravention of international refugee and human rights law as well as domestic law. As the applicant had claimed asylum immediately on arrival in the UK it would suggest that she had been detained purely on account of her illegal entry and notwithstanding evidence of torture. Pourgourides discusses several cases which provide an indication of the mental health effects of detention on asylum seekers. One Algerian man had been imprisoned on arrival in the UK despite evidence that he had been severely tortured when imprisoned for five months in Algeria. He had also been subjected to a short period in solitary confinement ${ }^{197}$. This experience had increased his anxiety and depression and led him to have suicidal thoughts.

The degree of anxiety is often intensified as people don't know precisely why they have been detained and for how long they may remain in detention ${ }^{198}$. Pourgourides' research reveals that the average period of detention in 1997 was 154 days; longer than the average remand period. Whilst a significant proportion of asylum seekers were then detained in prisons she notes the inherent uncertainty of such detention coupled with the added complication of backgrounds of trauma, homesickness, guilt and nostalgia. Her conclusions support those of the Amnesty report:

Detention results in severe psychological problems and is harmful to the mental health of detainees. It is abusive and inhumane. It recreates the environment of oppression, fear and uncertainty from which people have fled. In doing so, it compounds the stress they have endured, deprives them of their capacity to survive and creates new and pressing problems in host countries which are not currently being adequately dealt with $^{199}$.

Domanski describes refugee camps as 'total institutions' whereby a person will undergo desocialization, including a breakdown of family relationships and loss of social status ${ }^{200}$. This disengagement is fuelled by lack of regular information about process. The detainee will experience temporal and spatial disorientation as well as grief and anxiety - which leads to a

\footnotetext{
196 ibid. at 17-18.

${ }^{197}$ Pourgourides, Christina “The mental health implications of the detention of asylum seekers" pp199-209 in Hughes and Liebaut supra n18 at 201.

198 ibid. at 203.

199 ibid. at 208 .

${ }^{200}$ Domanski, Maciej “Insights from refugee experience: a background paper on temporary protection pp20-34 in Hathaway Reconceiving International Refugee Law at 24.
} 
sense of nothingness and uncertainty and, ultimately a feeling of overwhelming powerlessness and insignificance ${ }^{201}$. These feelings will intensify the longer a person is detained and thus is becomes essential to ensure that detention is a last resort which is confined to short periods where necessary to fulfil a legitimate objective. In advocating an integrationist approach, Watters also notes the detrimental mental health effect of detention ${ }^{202}$.

In the assessment of proportionality it is essential that these factors are fully appreciated before a decision to detain can be legitimately made.

\section{Alternatives to detention}

Whilst there is little research on the alternatives to detention in the UK there has been detailed research analysing the international position by Ophelia Field and Alice Edwards ${ }^{203}$. They point out the lack of data regarding non-detained asylum seekers who abscond which makes it difficult to assess whether there is a significant risk which could justify a detention policy ${ }^{204}$. However, the research also suggests that in destination states, asylum seekers are unlikely to abscond as they seek to be recognised as legitimate, lawful residents ${ }^{205}$. A study of 98 asylum seekers who were released on bail contrary to the wishes of the HO who believed they had a high chance of absconding found $90 \%$ maintained the bail conditions ${ }^{206}$. The evidence collated indicates that the provision of legal advice and support is likely to significantly reduce the potential to abscond ${ }^{207}$. The research demonstrates a wide range of potential alternatives which could be utilised by the state to maintain the objective of immigration control and security - the majority are likely to be far cheaper ${ }^{208}$ to administer and most present a less challenging environment for the potential

\footnotetext{
201 Domanski at 31.

202 Watters, Charles "The mental health needs of refugees and asylum seekers: key issues in research and service development” pp282-297 in Nicholson and Twomey at 287.

203 Field and Edwards Alternatives to detention of asylum seekers and refugees UNHCR Legal and Protection Policy Research Series POLAS/2006/03 April 2006.

204 ibid. para 89.

205 ibid. para 90.

${ }^{206}$ Bruegel, I and Natamba, E Maintaining contact: what happens after detained asylum seekers get bail? Social Science Research paper No 16 South Bank University London 2002.

207 supra n203 para 156.

${ }^{208}$ ibid. para 166-172 produces evidence from projects in countries including UK, Lithuania, Australia and the US which supports this conclusion.
} 
detainee. In particular, the only state-funded bail system - the Toronto bail programme which supports those with no community ties to raise bail monies would appear to offer an effective alternative in destination countries. Bail is only offered following an assessment and interview to ascertain the client's credibility and the program then operates a regular reporting mechanism in addition to offering legal advice and support ${ }^{209}$.

Field concludes that research is urgently needed on the question of absconding and alternatives to detention within the $\mathrm{UK}^{210}$. It is submitted that any solutions should seek to avoid further criminalisation of asylum seekers.

\section{Necessity: an essential component of proportionality?}

Ten-day detention without charge is not generally acceptable in the criminal justice process ${ }^{211}$. Detention on the grounds of mental illness is also narrowly defined and can only be legitimate on the basis of necessity i.e. when the person is suffering from a mental illness. Yet, the decision of the HL and ECtHR in Saadi rules that necessity is not a requirement for immigration detention ${ }^{212}$. Thus, it is apparent that asylum seekers have less of a claim to liberty than others. The judicial supervision found throughout the criminal justice process is considered by the EctHR to be unsuitable in the immigration context. This separation of necessity from arbitrariness and proportionality is a cause for concern as it is not possible to conceive of these concepts in isolation.

Fairness requires outcomes which are accurate, efficient and acceptable ${ }^{213}$. Whilst acknowledging that errors may occur in any system it is important that the margin of error is minimal. An error would surely occur if, as in one of the cases presented by Amnesty International, a torturesurvivor is detained on arrival in the absence of any particular concern that they would abscond or

209 ibid. appendix 1 Canada.

${ }^{210}$ ibid. appendix 1 UK.

${ }^{211}$ In the absence of a reasonable suspicion that a person may be connected with terrorist offences.

${ }^{212}$ Cornelisse supra n165 at105. 
self-harm. Some commentators argue that the error can be minimised if the detention is confined to 7-10 days ${ }^{214}$. Yet a focus on the length of detention alone should constitute only one factor in an assessment of proportionality. If asylum seekers are detained primarily on the basis of their country of origin, without adequate consideration of their individual circumstances and the validity of their claim, there is a significant possibility that victims of torture and trauma will experience short-term detention which is more likely to have a significant detrimental effect on their welfare.

We must consider whether such potential harm is proportionate to the need to ensure effective and efficient immigration control. A key factor in this assessment would surely be whether the person is at risk of absconding or otherwise evading the immigration authorities. Yet we know that Oakington is not regarded as suitable for such individuals. The Oakington regime is based purely on administrative convenience. Put simply the question of proportionality becomes whether $7-10$ days detention of persons who may have experienced torture or trauma can be justified for administrative convenience. Indeed, one could go further and ask is the short-term detention of any applicant justifiable on this basis?

Although the length of detention is a key issue that is linked to reasonableness by the ECtHR in Chahal, detention cannot satisfy the absence of arbitrariness criteria simply because it is comparatively brief $^{215}$. A brief detention is not per se reasonable or fair. A deprivation of liberty has occurred and therefore the rule of law and human rights standard demand that there is adequate justification. It has certainly been the case that the ECtHR has paid 'little attention to the fine print on proportionality and necessity in the context of immigration law ${ }^{216}$. The Saadi case marked the first opportunity for detailed analysis and the enumeration of specifics. Even if we accept that detention does not need to be necessary under international human rights law, it is

\footnotetext{
${ }^{213}$ Costello, Cathryn "The asylum procedures directive and the proliferation of safe country practice: deterrence, deflection and the dismantling of international protection” EJML 2005 Vol. 7 35-69 at 35.

${ }^{214}$ Brennan supra n6 at 131.

${ }^{215}$ Chahal v UK (1996) 23 EHRR 413.

${ }^{216}$ supra n165 at 104.
} 
clear that it must not be arbitrary and that this includes an assessment of proportionality. It is submitted that a deprivation of liberty in the absence of an individual assessment of its appropriateness or need, does not satisfy these requirements.

Detention can only be considered to be proportionate if it is rationally connected to the legitimate objective of immigration control. This is doubtful if we take a narrow view of immigration control and associate it with preventing the risk of absconding and illegal activities. However, as the ECtHR appears to afford a wide margin of appreciation to states to determine what immigration control requires, we may expect them to allow a broad interpretation on this point. Nevertheless, proportionality also requires an assessment that the means used to impair the right or freedom are no more than necessary to accomplish this objective. Thus we can see that necessity is not entirely irrelevant in the decision to restrict movement or deprive a person of their liberty. At the very least we would expect a consideration of alternatives to detention in the individual case, an individualised assessment of the need for detention and the health effects of detention. Amnesty International has described the decision to detain in the UK as a 'bed-lottery' which is arbitrary in that it lacks considerations of necessity and proportionality ${ }^{217}$. This includes cases apparently based on the risk of absconding but where Amnesty found that detained applicants had complied with all requests from the authorities ${ }^{218}$. As it is impossible to understand why some people are detained and not others with similar case histories, the conclusion must be that it is for deterrent purposes - apart from an increased vulnerability to detention of certain nationalities, the process appears arbitrary ${ }^{219}$.

\section{$\underline{\text { Conclusion }}$}

If there is concern over bogus asylum applications and the need to prevent abuse then we must acknowledge that non-entrée policies operate in an indiscriminate manner. Furthermore, non-

\footnotetext{
${ }^{217}$ Amnesty International supra n153 at 49.

218 ibid. at 52.
} 
arrival measures lock refugees to their region of origin which are also the regions with the largest number of refugees and the greatest refugee burden - therefore they act to 'cement existing injustices $^{, 220}$.

The UNHCR has been critical of the trend, particularly post Sept $11^{\text {th }} 2001$, to detain asylum seekers sometimes on a discriminatory basis depending primarily on country of origin ${ }^{221}$. They also emphasise that the necessary public support for the reception of asylum seekers has been hampered by the media and politicians tendency to conflate illegal migration with refugee movements ${ }^{222}$. The UNHCR return to this theme in the 2003 report which notes that despite the public sense of panic over illegal migration, the number of asylum applications had fallen the previous year in industrialised countries ${ }^{223}$. This pattern has since continued ${ }^{224}$.

Whilst the numbers of people detained on immigration grounds is increasing across Europe, its use has become less targeted ${ }^{225}$. If left unchecked it seems likely that more states will opt for administrative detention and as the number of detainees increases so will the duration of the confinement. The consequences of this development should not be under-stated. More people will be locked up for longer periods ${ }^{226}$. This is reprehensible on both an individual and societal level. For some, detention itself will be traumatic and for others it will add to the trauma of persecution already experienced. In either event, it is unlikely to assist integration should the detainee be awarded refugee status. On a societal level, it furthers the perception of non-EU immigrants,

\footnotetext{
${ }^{219}$ Teresa Hayter Open Borders, the case against immigration controls Pluto 2000 at 119.

${ }^{220}$ Gibney supra $\mathrm{n} 3$ at 15.

${ }^{221}$ UN GA Ex Comm of High Commissioners $53^{\text {rd }}$ session “Note on International Protection” A/AC.96/965 Sept $11^{\text {th }}$ 2002 para 44.

${ }^{222}$ UN GA Ex Comm of High Commissioners $53^{\text {rd }}$ session “Note on International Protection” A/AC.96/965 Sept $11^{\text {th }}$ 2002 para 45.

${ }^{223}$ UN GA Ex Comm of High Commissioners 54th session “Note on International Protection” A/AC.96/975 July 2nd 2003 para 55.

${ }^{224}$ UN GA Ex Comm of High Commissioners 56th session “Note on International Protection” A/AC.96/1008 $4^{\text {th }}$ July 2005 para 3.

${ }^{225}$ BID supra n125 at para 7.2.

${ }^{226}$ Bacon supra n16 observes that private companies operating immigration centres in the UK see this as an extension of the prison regime and as a highly profitable growth area p3
} 
asylum-seekers and refugees as 'different' and Outsiders ${ }^{227}$. In so-doing it fuels intolerance and racism. Asylum seekers are increasingly portrayed in the British media as 'undeserving' and the expansion of the detention estate has helped to fuel this view. Landgren argues that the increased use of detention 'enhances the perception that there is something amiss with that group of people. It contributes to animosity towards asylum seekers as a whole, 228 .

A brief period of detention may be viewed as a practical solution to the demands of immigration control $^{229}$. It could also be argued that where there is no previous history of torture or trauma, a brief period of confinement may be proportionate and acceptable. However, this conclusion ignores the legal, social, moral and financial objections that can be levied at short-term detention. Legally, detention in the absence of an individualised assessment of its suitability, is on shaky ground. International soft law requires both a consideration of alternatives prior to detention and that a decision be based on both necessity and proportionality.

Socially, the routine use of short-term detention, perpetuates the view that asylum seekers are criminals. As noted by the dissenting judgements of the Grand Chamber and the UNHCR, the terms immigrant and asylum seeker are becoming blurred ${ }^{230}$. This causes confusion and increases hostility as the latter t becomes misunderstood and marginalised ${ }^{231}$.

Morally, if one accepts Gibney’s contention that there is a humanitarian obligation owed to those fleeing persecution ${ }^{232}$, it is surely inappropriate to subject those people to detention where it is not strictly necessary. One could also defer to the rule of law which requires any deprivation of liberty to be based on narrowly prescribed, accessible criteria.

Financially, the cost of immigration detention far exceeds the economic cost of allowing a person to live freely in the community.

\footnotetext{
${ }^{227}$ Tuitt passim; Schuster, L “A comparative analysis of the asylum policy of Seven European Governments” Journal of Refugee Studies 2000 Vol. 13, 1p118-132 at 128

${ }_{228}^{228}$ Landgren supra 49 at 159.

${ }^{229}$ Hathaway, James The Rights of Refugees under International Law Cambridge Univ. press 2005

230 supra p31

${ }^{231}$ Tuitt supra n33 passim

${ }^{232}$ Supra n3
} 
There are no signs that the climate of restrictionism will abate in the near future. In 2007, the Home Office and Foreign and Commonwealth Office published their strategy to build stronger international alliances to manage migration ${ }^{233}$. The strategy includes increased off-shore border checks, much more emphasis on preventing abuse and controlling entry as well as a protection quota of up to 500 people year - surely an embarrassment given the number of people in need of protection and the rate of emigration from the UK.

The ECtHR were keen to emphasise the requirement that detention should not be arbitrary. Yet arbitrariness, which includes a test of proportionality, must surely require an individualised assessment of necessity. It also demands a consideration of alternative, less intrusive, measures. The detention of Dr Saadi can not be viewed as necessary to verify his identity as he had consistently maintained contact with the Home Office and thus it is difficult to see the justification for detention. It certainly does not appear to be based on an individual assessment of his particular circumstances. Saadi was detained because of his Iraqi nationality and a presumption, which turned out to be inaccurate, that his case could be speedily determined. Therefore a consideration of Article 14 in conjunction with Article 5 may have been more appropriate.

The ECtHR in Amuur recognised that while states may be legitimately concerned over immigration and attempts to evade immigration control this cannot be used to legitimise the denial of rights to asylum seekers as guaranteed by international refugee and humanitarian law ${ }^{234}$. Yet the decision in Saadi effectively endorses such a denial providing it is for a short period of time.The use of detention for administrative purposes does not satisfy the tests of proportionality and lack of arbitrariness. It is also entirely at odds with the view of the UNHCR that detention

\footnotetext{
${ }^{233}$ Home office and Foreign and Commonwealth Office Managing Migration. A strategy to build stronger international alliances to manage migration June 2007.

${ }^{234}$ Amuur v France App No 19776/92 of $25^{\text {th }}$ June 1996 para 43.
} 
should in principle be avoided ${ }^{235}$. The dissenting judgements of the Grand Chamber offer a pertinent conclusion:

Ultimately, we are now also to accept that Article 5 of the Conevntion, which has played a major role in ensuring controls of arbitrary detention, should afford a lower level of protection as regards asylum and immigration which, in social and human terms, are the most crucial issues facing us in the years to come? I it a crime to be a foreigner? We do not think so 236

${ }^{235}$ General Assembly EX Com of the High Commissioners programme $52^{\text {nd }}$ session "Note on international protection" A/AC.96/951 13tg Sept 2001 para 46; EXCOM Conclusions 44 (XXXVII) 1986; 85 (XLIX) 1998, paras cc,dd,ee.

${ }^{236}$ Grand Chamber [2008] dissenting opinions 